KERAGAAN AWAL KELAPA SAWIT DI LAHAN RAWA PASANG SURUT (STUDI KASUS KEBUN REVITALISASI RAWAPITU KABUPATEN TULANG BAWANG, LAMPUNG)

\title{
OIL PALM DEVELOPMENT ON THE TIDAL SWAMP LAND (CASE STUDY RAWAPITU REVITALIZATION PROGRAM KABUPATEN TULANG BAWANG, LAMPUNG)
}

\author{
Sumaryanto, Heri Santoso ${ }^{1^{*}}$ dan Fandi Hidayat ${ }^{1}$ \\ ${ }^{1}$ Pusat Penelitian Kelapa Sawit (PPKS), Medan 20158 \\ ${ }^{*}$ Corresponding author: sumaryantosp@yahoo.com
}

\begin{abstract}
Indonesia has around 20.11 million hectares of tidal swamp land area and about 2.07 million hectare is tidal swamp potential. The results of the inventory report BPTP Lampung in 2012 revealed that the area of swamp land in Lampung Province 108 thousand ha consisting of 56 thousand ha of tidal swamp and 52 thousand ha of lowland swamp.The main issues management of tidal swamp land is the water level always changing and the sulfidic or pyrite layer. Application water system design are good enough to prevent it. The rain distribution on Rawapitu about 39-531 mm during 2013-2014 and there were 2-3 month dry season. The fluctuation of water level on piezometer showed that the areal flooded on December 2013 and April 2014. It has affected the oil palm growth although increasing the number of frond, rachis length, and leaf area indeks.
\end{abstract}

Keywords: oil palm, tidal swamp, water table

\begin{abstract}
ABSTRAK
Sebaran lahan pasang surut di Indonesia mencapai 20,11 hektar namun hanya sekitar 2,07 hektar yang dapat dikembangkan. Areal rawa pasang surut yang terdapat di propinsi Lampung sekitar 56 ribu hektar yang sebagian dikelola untuk pengusahaan kelapa sawit seperti di Rawapitu kabupaten Tulang Bawang propinsi Lampung. Pengelolaan lahan pasang surut terdapat kendala yaitu kondisi permukaan air yang selalu berubah dan kedalaman lapisan sulfidik atau pirit dalam tanah.Untuk mengendalikan kondisi muka air tanah pada waktu pasang naik maupun surut, maka perlu penerapan tata kelola air yang baik. Kondisi distribusi hujan di kebun Rawapitu berkisar 39 - $531 \mathrm{~mm}$ per bulan dan terdapat 2-3 bulan kering pada 2013 dan 2014. Sedangkan fluktuasi permukaan air tanah yang diukur menggunakan piezometer menunjukkan bahwa terjadi genangan pada bulan Desember 2013 dan sebagian April 2014. Fluktuasi muka air tersebut mempengaruhi kondisi pertumbuhan tanaman di sekirar piezometer meskipun secara umum mengalami peningkatan jumlah pelepah, panjang rachis dan indeks luas daun.
\end{abstract}

Kata kunci: kelapa sawit, pasang surut, muka air 
PENDAHULUAN

Perkembangan perkebunan kelapa sawit pada tahun 2011 mencapai 8.9 juta ha, meningkat menjadi 9.2 juta ha pada tahun 2012 (Amelia et. al., 2012). Lahanlahan potensial untuk perkebunan kelapa sawit saat ini sudah sangat terbatas, sehingga perluasan lahan yang banyak dilakukan mengarah pada lahan-lahan marjinal. Pengelolaan lahan marjinal untuk perkebunan kelapa sawit bertujuan untuk menggali potensi lahantidak produktif agar dapat termanfaatkan dan lebih bernilai ekonomi. Pengelolaan lahan marjinal yang intensif dapat menunjang pertumbuhan tanaman. Masukan teknologi dan penerapan Best Management Practises mutlak dilakukan untuk dapat memaksimalkan potensi tanaman.

Lahan pasang surut dan gambut merupakan salah satu lahan sub optimal yang berpotensi untuk pengembangan tanaman kelapa sawit. Namun demikian, pemanfaatan lahan-lahan tersebut harus didasarkan pada kesesuaian antara persyaratan tumbuh kelapa sawit dengan karakteristik spesifik lahannya (Winarna et al., 2007; Winarna dan Sutarta, 2010). Luas lahan pasang surut yang tersebar di seluruh Indonesia sekitar 20.11 juta hektar diantaranya 2.07 juta hektarnya merupakan lahan pasang surut potensial (Alihamsyah, 2002).Hasil laporan kegiatan inventarisasi Balai Pengkajian Teknologi Pertanian Lampung pada tahun 2012mengungkapkan bahwa luasan lahan rawa di Provinsi Lampung 108 ribu ha terdiri dari 56 ribu ha rawa pasang surut dan 52 ribu ha rawa lebak (Hafif, 2013).Adanya program Revitalisasi Pertanian yang dicanangkan pemerintah membuka peluang masyarakat dalam mengembangkan lahan pasang surut untuk budidaya kelapa sawit seperti di Rawapitu kabupaten Tulang Bawang propinsi Lampung.

Permasalahan utama pada pengelolaan lahan pasang surut adalah kondisi permukaan air yang berubah-ubah. Pada saat air surut permukaan air dapat mencapai lebih tinggi dari50 $\mathrm{cm}$, sedangkan ketika pasang kondisi lahan tergenang.Pengolahan tanah di lahan pasang surut sulfat masam harus diupayakan tidak terlalu dalam, karena lapisan pirit dan sulfidik umumnya berada pada kedalaman kurang dari 50 cm,sehingga terangkat kepermukaan, mudah teroksidasi dan mengeluarkan besi fero $\left(\mathrm{Fe}^{2+}\right)$ dan sulfat yang meracun bagi tanaman (Nurita, et. al., 2014; Priatmadi et. al., 2009). Selain itu kondisi tanah masam dapat meningkatkan kelarutan ion $\mathrm{Al}^{3+}, \quad \mathrm{Fe}^{2+}, \quad$ dan $\mathrm{Mn}^{2+}$ kemudian menyebabkan kation-kation basa seperti $\mathrm{Ca}^{2+}, \mathrm{Mg}^{2+}, \mathrm{K}^{+}$dan $\mathrm{Na}^{+}$terdesak keluar dari komplek jerapan tanah (Sa'ad et. al., 
2011). Akibatnya produktivitas lahan menjadi menurun.Penerapandesain tata air yang baikdapat mencegah hal tersebut.Sistem tata air ini mempunyai tujuan untuk memenuhi kebutuhan air pada saat penyiapan lahan dan pertumbuhan tanaman. Selain itu dengan adanya desain tata airdapat memperbaiki kondisi lahan, seperti: pencucianakumulasi

\section{BAHAN DAN METODE}

Penelitian dilakukan dengan metode survei di kebun program revitalisasi kelapa sawit Rawapitu lingkup PT Perkebunan Nusatara VII (Persero) kabupaten Tulang Bawang, Lampung pada tahun2013-2014. Luas areal 35,4 ha menggunakan bahan tanaman yang berasal dari Pusat Penelitian Kelapa Sawit. Tanaman kelapa sawit ditanam pada kerapatan 140 pohon/hadengan pola segitiga samasisi.

Pengamatan profil tanah dilakukan hingga kedalaman 1,5 $\mathrm{m}$ dari permukaan tanah. Di dalam blok kemudian dipasang piezometer pada 9 titik secara acak.Pemasangan piezometer dilakukan berdasarkan karakteristik lahan terkait dengan sebaran mikrotopografi yang terdapat di areal penelitian.

Selain itu dilakukan pengukuran terhadap pertumbuhan kelapa sawit. Pengamatan pertumbuhan kelapa sawit dilakukan terhadap tanaman di sekitar racun, pergantian air yang yang lebih segar secara berkala, dan mempertahankan lapisan pirit tetap dalam tereduksi (Widjaya et. al., 1998).Adanya pengelolaan ini harus dibarengi dengan kondisi pertumbuhan tanaman yang optimal. Oleh karena itu perlu dilakukan kajian terhadap pertumbuhan kelapa sawit pada lahan pasang surut.

piezometerpada Desember 2013 dan Desember 2014. Parameter yang diamati adalah jumlah pelepah, panjang pelepah (m), jumlah anak daun, dan indeks luas daun.

Pengukuran terhadap panjang pelepah dilakukan dengan menggunakan meteran dari permukaan tanah hingga pangkal duri rachis pada pelepah ke-9. Perhitungan jumlah pelepah dilakukan secara manual dengan menghitung seluruh pelepah yang dihasilkan tanaman pada saat pengamatan. Pada pelepah yang sama dilakukan perhitungan juga terhadap jumlah anak daun (helai daun) pada 1 sisi mulai dari duri rachis hingga ujung daun pelepah ke-9. Selanjutnya dilakukan pengukuran terhadap panjang dan lebar anak daun. Sampel anak daun yang diukur berjumlah 6helai, terletak di sisi kiri dan kanan peralihan permukaan petiol (punggung kuda).Seluruh data hasil pengamatan dilakukan analisis statistik dan 
uji lanjut DMRT dengan tingkat kepercayaan $95 \%$.

\section{HASIL DAN PEMBAHASAN}

\section{Kondisi Lahan}

Areal Rawapitu merupakan rawa belakang dari lembah aluvial luas yang terpengaruh oleh aliran sungai Pidada dan Tulang Bawang. Berdasarkan pengamatan profil tanah, tergolong dalam Sulfic Endoaquepts, bertekstur tanah liat, struktur tanah masif, drainase sangat terhambat, kandungan batuan $<3 \%$, kedalaman sulfidik >80 cm; pH 3,8-4,2; bentuk wilayah datar, ketinggian tempat $20 \mathrm{~m} \mathrm{dpl}$.

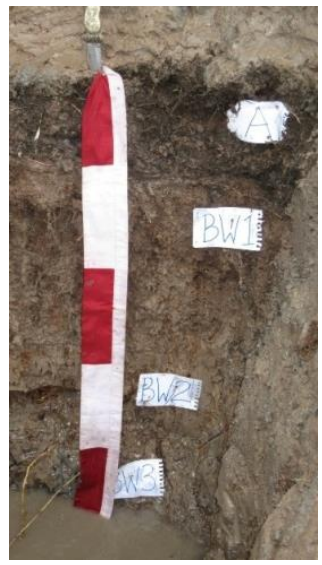

Gambar 1. Profil tanah di areal Rawapitu

\section{Kondisi Curah Hujan}

Secara umum distribusi hujan di lokasi penelitian berkisar antara 39 - 531 mm per bulan. Terdapat bulan kering pada tahun 2013 yaitu Mei dan SeptemberOktober sedangkan pada tahun 2014 secara berturut-turut bulan kering terjadi pada bulan Agustus-Oktober. Adanya bulan kering yang terjadi berturut-turut menyebabkan penurunan permukaan air tanah. Pada lahan rawa pasang surut penurunan muka air ini dapat memicu tereksposnya lapisan pirit dan sulfidik sehingga dapat meracuni tanaman. Sebaran curah hujan di lokasi penelitian pada tahun 2013 dan 2014 disajikan pada Gambar 1. 


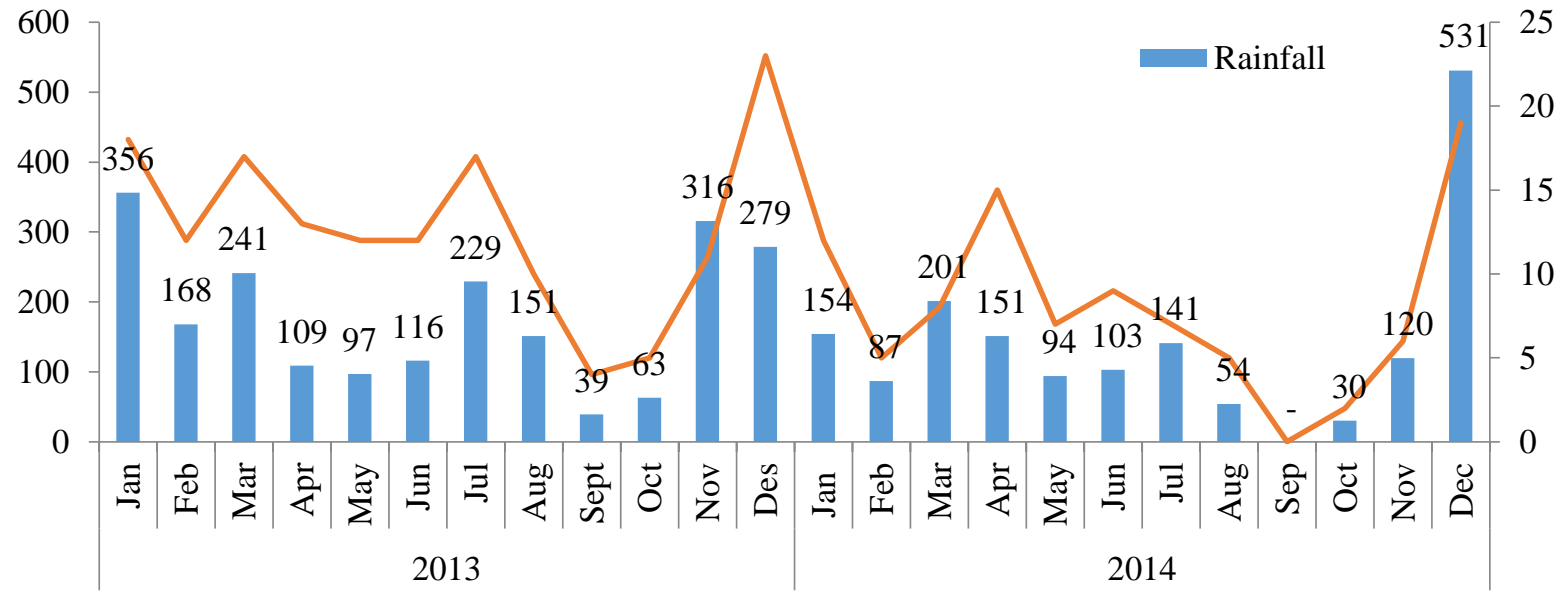

Gambar 2. Sebaran curah hujan di lokasi penelitian pada tahun 2013 dan 2014.

\section{Kondisi Pengukuran Muka Air Tanah}

Hasil pengukuran muka air tanah yang dilakukan pada periode SeptemberDesember 2013 menunjukkan bahwa permukaan air tanah pada setiap piezometer berfluktuasi hal tersebut dipengaruhi oleh kondisi curah hujan yang terjadi pada setiap bulannya. Pada akhir tahun 2013 di bulan November-Desember curah hujan mencapai 279-316 mm jauh lebih tinggi dibandingkan dengan curah hujan bulan September-Oktober sehingga terjadi kenaikan muka air tanah hingga 20 $\mathrm{cm}$ di atas permukaan tanah (tergenang). Meskipun demikian sepanjang Maret-Mei 2014 mempunyai curah hujan lebih rendah dibandingkan periode NovemberDesember rata-rata muka air tanah pada kisaran $0-40 \mathrm{~cm}$ di bawah permukaan tanah.

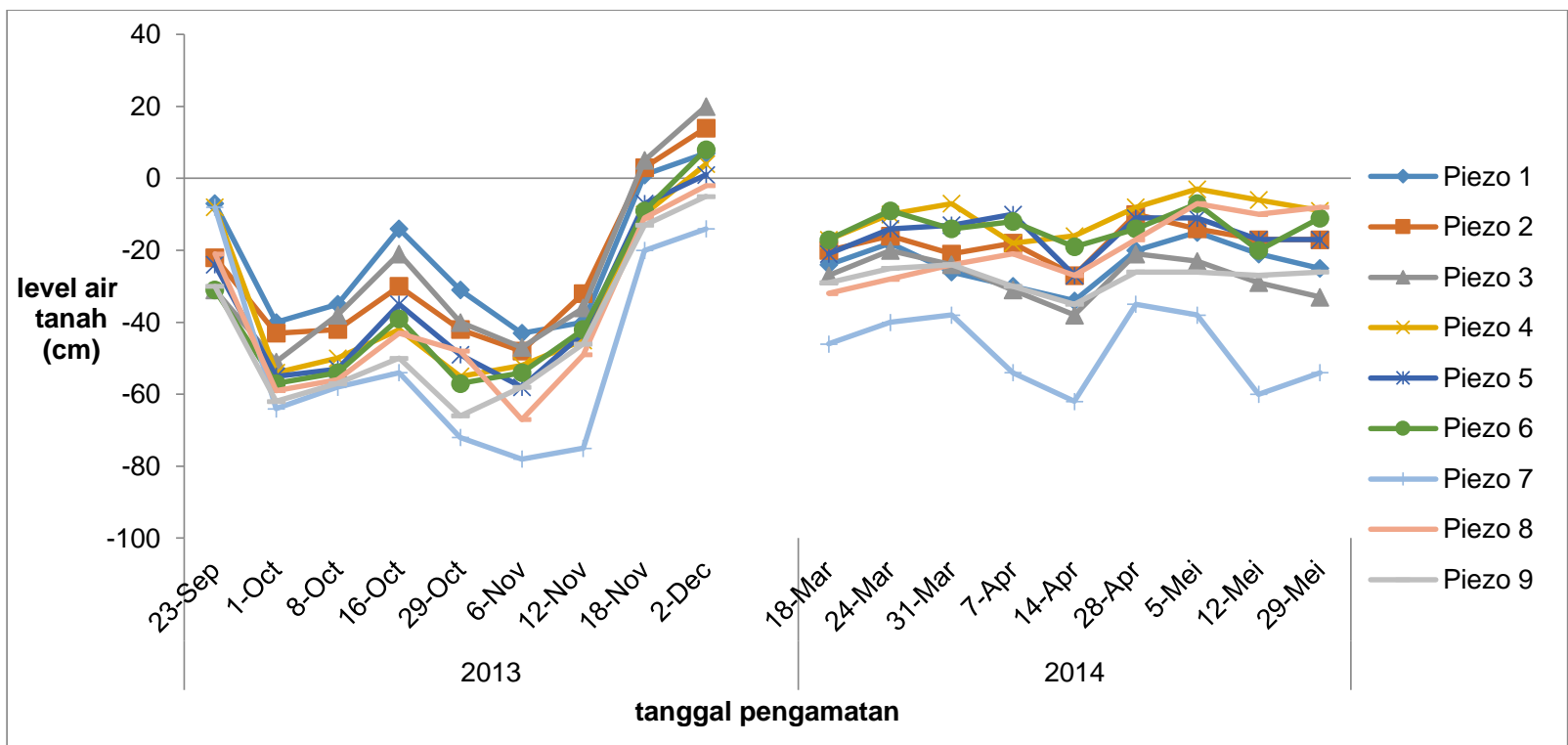

Gambar 3. Fluktuasi muka air tanah pada bulan September-Desember 2013 dan bulan MaretMei 2014. 
Performa Pertumbuhan Tanaman

Jumlah pelepah kelapa sawit di lahan pasang surut disajikan pada Tabel 1. Kisaran jumlah pelepah kelapa sawit pada Desember 2013 menunjukkan nilai yang tidak berbeda nyata. Pertambahan jumlah pelepah dalam peroide 1 tahun pada setiap kondisi muka air dalam pipa piezometer berkisar 13-21 pelepah. Pertambahan pelepah ini cukup rendah karena pertambahan jumlah pelepah akan menurun seiring dengan bertambahnya usia tanaman. Pada umumnya pertambahan pelepah menjadi stabil pada usia 8-12 tahun dengan pertambahan pelepah mencapai 20-24 pelepah/tahun (Corley and Thinker, 2003). Hal ini diduga bahwa kondisi tanaman mengalami stress sehingga pertumbuhan vegetatif pada beberapa pipa piezometer sedikit terhambat ditandai dengan pertambahan pelepah yang sedikit terutama tanaman kelapa sawit di sekitar pipa 8.

Tabel 1. Jumlah pelepah dan panjang rachis kelapa sawitpada Desember 2013 dan Desember 2014.

\begin{tabular}{|c|c|c|c|c|c|c|}
\hline \multirow{2}{*}{ Titik } & \multicolumn{2}{|c|}{ Jumlah Pelepah } & \multirow{2}{*}{ Pertambahan } & \multicolumn{2}{|c|}{ Panjang Rachis (m) } & \multirow{2}{*}{ Pertambahan } \\
\cline { 2 - 3 } & Des 2013 & Des 2014 & & Des 2013 & Des 2014 & \\
\hline Pipa 1 & $41.00 \mathrm{a}$ & $57.83 \mathrm{bcd}$ & 16.83 & $2.32 \mathrm{a}$ & $2.92 \mathrm{a}$ & 0.60 \\
\hline Pipa 2 & $33.25 \mathrm{a}$ & $59.67 \mathrm{ab}$ & 26.42 & $2.01 \mathrm{ab}$ & $2.72 \mathrm{abc}$ & 0.71 \\
\hline Pipa 3 & $40.25 \mathrm{a}$ & $61.08 \mathrm{a}$ & 20.83 & $2.20 \mathrm{ab}$ & $2.53 \mathrm{bc}$ & 0.33 \\
\hline Pipa 4 & $31.50 \mathrm{a}$ & $53.25 \mathrm{~cd}$ & 21.75 & $1.87 \mathrm{~b}$ & $2.66 \mathrm{abc}$ & 0.79 \\
\hline Pipa 5 & $37.50 \mathrm{a}$ & $55.58 \mathrm{abcd}$ & 18.08 & $2.06 \mathrm{ab}$ & $2.82 \mathrm{ab}$ & 0.76 \\
\hline Pipa 6 & $34.50 \mathrm{a}$ & $54.67 \mathrm{bcd}$ & 20.17 & $1.93 \mathrm{ab}$ & $2.63 \mathrm{abc}$ & 0.70 \\
\hline Pipa 7 & $35.75 \mathrm{a}$ & $53.17 \mathrm{~cd}$ & 17.42 & $1.97 \mathrm{ab}$ & $2.67 \mathrm{abc}$ & 0.71 \\
\hline Pipa 8 & $37.75 \mathrm{a}$ & $50.92 \mathrm{~d}$ & 13.17 & $2.09 \mathrm{ab}$ & $2.47 \mathrm{c}$ & 0.38 \\
\hline Pipa 9 & $40.50 \mathrm{a}$ & $57.00 \mathrm{abc}$ & 16.50 & $2.22 \mathrm{ab}$ & $2.58 \mathrm{bc}$ & 0.37 \\
\hline
\end{tabular}

Keterangan: Angka-angka yang diikuti oleh huruf yang sama pada kolom yang sama tidak berbeda nyata menurut uji DMRT pada taraf kepercayaan $95 \%$.

Perkembangan panjang rachis kelapa sawit pada Desember 2013 hingga Desember 2014 menunjukkan bahwa secara umum rachis paling pendek terdapat pada tanaman kelapa sawit disekitar pipa 4 dan pipa 8. Meskipun demikian dalam periode 1 tahun tersebut tanaman kelapa sawit di sekitar pipa 4 mengalami peningkatan panjang rachis yang tertinggi.
Peningkatan panjang rachis tanaman kelapa sawit tentunya juga akan meningkatkan jumlah anak daun pada setiap pelepahnya. Kenaikan jumlah anak daun juga meningkatkan luasan daun sehingga fotosintesis menjadi lebih tinggi. Hasil fotosistesis berupa asimilat disalurkan ke seluruh bagian tanaman untuk mendukung perkembangan sel-sel 
dan jaringan tanaman dalam membentuk bahan kering (Gardneret. al., 1991).

Panjang rachis, dan jumlah anak daun membentuk bagian vegetatif tanaman yaitu pelepah. Pelepah(daun) merupakan organ vegetatif tanaman kelapa sawit yang diperlukan untuk penyerapan dan pengubahan energi matahari yang digunakan dalam proses asimilasi. Semakin bertambah usia tanaman maka pertambahan ukuran pelepah juga semakin besar

Tabel 2.Jumlah anak daun dan Indeks Luas Daun kelapa sawit pada Desember 2013 dan Desember 2014.

\begin{tabular}{|c|c|c|c|c|c|c|}
\hline \multirow{2}{*}{ Titik } & \multicolumn{2}{|c|}{ Jumlah anak daun } & \multirow{2}{*}{ Pertambahan } & \multicolumn{2}{|c|}{ Indeks Luas Daun } & \multirow{2}{*}{ Pertambahan } \\
\cline { 2 - 3 } & Des 2013 & Des 2014 & & Des 2013 & Des 2014 & \\
\hline Pipa 1 & $198.00 \mathrm{a}$ & $234.67 \mathrm{a}$ & 36.67 & $1.50 \mathrm{a}$ & $2.35 \mathrm{a}$ & 0.85 \\
\hline Pipa 2 & $190.00 \mathrm{ab}$ & $227.33 \mathrm{ab}$ & 37.33 & $0.96 \mathrm{ab}$ & $2.29 \mathrm{a}$ & 1.33 \\
\hline Pipa 3 & $190.00 \mathrm{ab}$ & $213.83 \mathrm{bc}$ & 23.83 & $1.43 \mathrm{a}$ & $2.22 \mathrm{a}$ & 0.79 \\
\hline Pipa 4 & $179.50 \mathrm{ab}$ & $210.33 \mathrm{c}$ & 30.83 & $0.80 \mathrm{~b}$ & $2.21 \mathrm{a}$ & 1.41 \\
\hline Pipa 5 & $182.00 \mathrm{ab}$ & $213.67 \mathrm{bc}$ & 31.67 & $0.99 \mathrm{ab}$ & $2.08 \mathrm{ab}$ & 1.09 \\
\hline Pipa 6 & $189.50 \mathrm{ab}$ & $211.50 \mathrm{bc}$ & 22.00 & $0.82 \mathrm{~b}$ & $1.58 \mathrm{c}$ & 0.75 \\
\hline Pipa 7 & $189.00 \mathrm{ab}$ & $213.33 \mathrm{bc}$ & 24.33 & $1.11 \mathrm{ab}$ & $1.76 \mathrm{bc}$ & 0.65 \\
\hline Pipa 8 & $194.00 \mathrm{ab}$ & $213.67 \mathrm{bc}$ & 19.67 & $1.10 \mathrm{ab}$ & $1.24 \mathrm{~d}$ & 0.14 \\
\hline Pipa 9 & $174.50 \mathrm{~b}$ & $212.33 \mathrm{bc}$ & 37.83 & $1.17 \mathrm{ab}$ & $1.73 \mathrm{c}$ & 0.56 \\
\hline
\end{tabular}

Keterangan: Angka-angka yang diikuti oleh huruf yang sama pada kolom yang sama tidak berbeda nyata menurut uji DMRT pada taraf kepercayaan $95 \%$.

Pada umumnya lahan rawa pasang surut merupakan tanah yang terbentuk dari bahan induk yang banyak mengandungsenyawa pirit $\left(\mathrm{FeS}_{2}\right)$, hal ini dapat meningkatkan $\mathrm{pH}$ tanah (Toyibah, 2006; Shamsuddin et.al., 2006). Kondisi ini menjadikan tanah menjadi masam dan laju pencucian basa-basa ( $\mathrm{Ca}, \mathrm{Mg}$, dan $\mathrm{K}$ ) tinggi (Susilawati et.al., 2011).Hal inilah yang diduga menyebabkan pertumbuhan vegetatif tanaman kelapa sawit pada beberapa pipa terhambat.

Selain itu faktor genangan akibat kelebihan air juga diduga dapat menyebabkan kondisi tanaman tertekan karena genangan tersebut dapat bersifat periodik maupun permanen. Bagi tanaman kelapa sawit kondisi ini memiliki dampak yang buruk terutama berupa terhambatnya perkembangan akar akibat kondisi anaerob yang menekan respirasi perkaran. Kondisi ini juga mengakibatkan penurunan ketersediaan hara dalam tanah yang mengakibatkan defisiensi hara dan menghambat pertumbuhan tanaman (Sutarta dan Winarna, 2009).Timbulnya genangan pada tanah menyebabkan akumulasi $\mathrm{NH}^{+}$, ketidakstabilan $\mathrm{NO}^{-}$ dan makin rendahnya kebutuhan $\mathrm{N}$ untuk dekomposisi bahan organik sebagai akibat 
dari dekomposisi yang tidak sempurna dari residu tanaman oleh bakteri anaerob. Adanya genangan juga menyebabkan terjadinya reduksi feri oksida ke fero hidroksida dan melepaskan sebagian fosfat yang tersekap dalam tanah. Fraksi fosfat yang terlepas ini merupakan fraksi fosfat yang paling sukar melarut dan secara keseluruhan tidak dapat tersedia untuk tanaman. Novizan (2002) menyebutkan bahwa persediaan kalium di dalam tanah dapat berkurang karena tiga hal, yaitu pengambilan kalium oleh tanaman, pencucian kalium oleh air, dan erosi tanah. Pada pupuk $\mathrm{K}$, genangan mendorong pelepasan ion $\mathrm{K}^{+}$dan tertukarkan ke dalam bentuk dapat larut. Hal ini akan memicu reduksi $\mathrm{Fe}^{+}$dan $\mathrm{Mn}^{+}$yang mempunyai efek racun bagi tanaman (Engelstad, 1997).

\section{SIMPULAN}

Keragaan awal tanaman kelapa sawit di kebun Rawapitu pada umumnya tergolong baik meskipun terjadi fluktuasi level air tanah. Selain itu kedalaman lapisan pirit berada $>80 \mathrm{~cm}$ dari permukaan tanah. Secara umum pengusahaan kelapa sawit pada lahan pasang surut dapat dilakukan namun harus memperhatikan konservasi lahan dengan memperhatikan kedalaman sulfidik dan pengelolaan tata air yang tepat untuk menjaga agar lapisan sulfidik tidak teroksidasi dan terjadinya genangan sehingga tidak mengganggu keragaan tanaman.

\section{UCAPAN TERIMA KASIH}

Penulis mengucapkan terimakasih kepada Direksi PT. Perkebunan Nusantara VII (Persero) terutama seluruh karyawan Kebun Program Revitalisasi Rawa Pitu, Unit Usaha Bekri, Lampung atas ijin dan segala bantuanuntuk kelancaran penelitian ini.Tak lupa penulis juga mengucapkan terimakasih kepada Pusat Penelitian Kelapa Sawit (PPKS) yang telah mendukung sepenuhnya kegiatan ini.

\section{DAFTAR PUSTAKA}

Amalia, R., M.A. Agustira, dan T. Wahyono, 2012. Statistik Industri Kelapa Sawit 2012. Pusat Penelitian Kelapa Sawit. Medan.

Alihamsyah, T.,2002. Optimalisasi Pendayagunaan Lahan Rawa Pasang Surut. Makalah disajikan pada Seminar Nasional Optimalisasi Pendayagunaan Sumberdaya Lahan di Cisarua, tanggal 6-7 Agustus 2002. Puslitbang Tanah dan Agroklimat.

Corley, R.H.V., and P.B. Thinker, 2003. The Oil Palm. Great Britain: Blackwell Science Ltd, Blackwell Publishing Company. $608 \mathrm{hlm}$

Engelstad, O.P. 1997. Teknologi dan Penggunaan Pupuk. Terjemahan 
Goenadi. Gadjah Mada Universiy Press, Yogyakarta.

Gardner, F.P., R.B. Pearce, dan R.I. Mitchel, 1991. Fisiologi Tanaman Budidaya, alih bahasa H. Susilo. Jakarta: UI Press.

Hafif, B., 2013. Keragaan lahan suboptimal dan perbaikan produktivitas melalui kebijakan daerah di Lampung. Seminar Nasional Inovasi Teknologi Pertanian. Balai Pengkajian Teknologi Pertanian. Lampung.

Novizan, 2002. Petunjuk Pemupukan yang Efektif. Agro Media Pustaka, Jakarta

Nurita, dan A. Isdijanto, 2014. Peningkatan produksi padi berkelanjutan pada lahan rawa Pasang surut. Jurnal Teknologi Pertanian 9(1):1-7.

Priatmadi, B.H., dan A. Haris, 2009. Reaksi pemasaman senyawa pirit pada tanah rawa pasang surut. Jurnal Tanah Tropika 14 (1): 19-24.

Sa'ad, A., S. Sabiham, A. Sutandi, B. Sumawinata, dan M. Ardiansyah, 2011. Perubahan Karakteristik Lahan Pasang Surut (Studi Kasus Reklamasi di Delta Berbak, Jambi). Jurnal Penelitian Universitas Jambi Seri Sains 13 (2): 05-10.

Shamsuddin, J and M. Sarwani, 2002. Pyrite in acid sulfate soils: transformation and inhibition of its oxidation by application of natural materials. $17^{\text {th }}$ WCCS $14-$ 21 August 2002, Thailand. Paper No. 97: 1-5

Susilawati, A., dan A. Fahmi,2011. Peran bahan organik dalam meningkatkan efisiensi pemupukan fosfat pada tanah sulfat masam. J Sumberdaya lahan 5(1): 24-32.

Sutarta, E.S. dan Winarna. 2009. Beberapa Masalah Kritis di Bidang Tata Air dan pemupukan untuk Mendukung Kelapa Sawit di Lahan Pasang Surut. Seminar Nasional. Bandung 2009.

Toyibah, N., 2006. Pengaruh pencucian dan penggenangan tanah sulfat masam terhadap sifat kimia tanah. Skripsi. Fakultas Pertanian Unlam. Banjarbaru.

Widjaya-Adhi, IPG dan T. Alihamsyah., 1998. Pengembangan lahan pasang surut: potensi, prospek, dan kendala serta teknologi pengelolaannya untuk pertanian. Makalah Seminar dan Kongres Himpunan Ilmu Tanah Indonesia (HITI). Malang, 18 Desember 1998.

Winarna, D. Wiratmoko, E.S. Sutarta, S. Rahutomo, dan Sujadi. 2007. Potensi dan kendala Lahan Pasang Surut untuk budidaya Tanaman Kelapa Sawit. Seminar Nasional Lahan Rawa, Balai Penelitian Lahan Rawa, Kuala Kapuas.

Winarna dan E. S. Sutarta. 2010. Determining peatland properties that affect oil palm productivity: case study in Labuhan Batu Distric, North Sumatra. Proceeding of International Oil Palm Conference, 1-3 June 2010. Yogyakarta. Indonesia. 